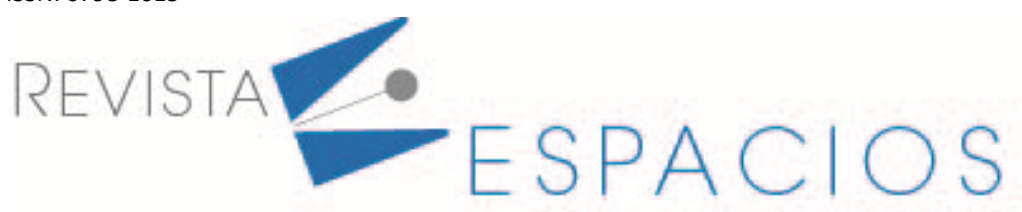

\title{
Approach to the concept of religious freedom. Case study: Colombia (South America)
}

\section{Acercamiento al concepto de libertad religiosa. Estudio de caso: Colombia (América del Sur)}

\author{
RENDÓN M., Alba L. ${ }^{1}$ \\ GUIO C., Rosa E. ${ }^{2}$ \\ RODRÍGUEZ M., Juan P. ${ }^{3}$ \\ SÁNCHEZ C., Juan M. ${ }^{4}$
}

\begin{abstract}
This document considers the aspects of the analysis of limits in the exercise of the right to religious freedom, worship and conscience, it is an issue of special relevance considering that it is not an "unrestricted and erga omnes" right because there are limits based on respect for the rights of others. It is necessary to promote a culture of respect and tolerance for fundamental freedoms of religion, worship and conscience, promote interreligious dialogue through the design, socialization and implementation of the Fundamental Public Policy on Religious Freedom in Bogota, which constitutes the full exercise of the guarantees established by the International Standards as well as the Colombian Political Constitution, to ensure the recognition and benefits of the practice of the fundamental right to religious freedom, worship and conscience in the various families existing today in society, for which it is also necessary to make the right visible, prevent, denounce and punish those who violate it.

Key words: religious freedom, fundamental right, tolerance, family.

\section{Resumen}

Este trabajo considera los aspectos del análisis de los límites en el ejercicio del derecho a la libertad religiosa, cultos y conciencia, es un tema de especial relevancia teniendo en cuenta que no es un derecho "irrestricto y erga omnes" y que se encuentran límites basados en el respeto a los derechos de los demás. Es necesario promover una cultura de respeto y tolerancia a las libertades fundamentales de religión, culto y conciencia mediante la adopción, socialización e implementación de la Política Pública Fundamental de Libertad Religiosa en Bogotá, que constituye el pleno ejercicio de las garantías que la Constitución establece en beneficio y reconocimiento de la importancia de las familias en la sociedad.

Palabras clave: normatividad, libertad religiosa, conceptualización
\end{abstract}

\section{Introduction}

The universal right to religious freedom is a fundamental human right and, although it is an issue whose nature and scope can be addressed from psychological, theological, historical or philosophical perspectives, this

\footnotetext{
${ }^{1}$ Abogada. Maestría en Derecho de Familia. Facultad de Derecho. Universidad Antonio Nariño (Bogotá, Colombia). Correo electrónico: arendon03@uan.edu.co, albaluciarm29@hotmail.com

2 Docente. Facultad de Derecho. Universidad Antonio Nariño (Bogotá, Colombia). Correo electrónico: reguio@ucatolica.edu.co

3 Profesor Titular. Facultad del Medio Ambiente y Recursos Naturales. Universidad Distrital Francisco José de Caldas. Correo electrónico: jprodriguezm@udistrital.edu.co

${ }^{4}$ Profesor Asociado. Facultad de Ingeniería. Universidad Distrital Francisco José de Caldas. Correo electrónico: jmsanchezc@udistrital.edu.co
} 
research is approached from a purely legal perspective, since it is a matter of rights without religion. Religious freedom is directly related to different behaviors that correspond to the private jurisdiction of individuals and over which the State has no control and as guaranteed in Colombia, a person's right to profess (externalize) any religious belief, not to profess any, to change or abandon the current one at any time of its existence.

This freedom includes all those behaviors that are directly related to the external manifestations of religiosity and which can therefore have a strong impact on society, is the recognition of the social dimension of the religious phenomenon, which for the same reason justifies the intervention of the State, in order to protect the fundamental rights and freedoms of others and public order, within the framework of a democratic society, in which the exercise of this and other freedoms must be guaranteed to all persons and groups present in the social conglomerate, ensuring the peaceful and harmonious coexistence of all, in strict respect and tolerance for individual and group differences.

Worship is one of the elements of religion, along with beliefs, feelings, and moral principles. Man's religious life does not develop only externally, nor is it limited to the fulfillment of some rites. The life of the religious man includes, as read in article 18 of the International Covenant on Civil and Political Rights, "worship, the celebration of rites, practices and teaching". (United Nations - Human Rights, 1966).

According to the above, this manuscript establishes a conceptual approach to the right to religious freedom, in the Latin American context and especially in Colombia.

\section{Approach to the concept in the context of colombia}

According to the International Covenant on Civil and Political Rights of December 16, 1966, which entered into force on March 23, 1976, in accordance with Article 49, subsequently the Constitutional Court makes a new ruling in which it clarifies the two terms, starting from of a judgment of a theological nature, presupposing in religion the existence of a god, and consequently of a cult. Indeed, as has been said, religion consists of a personal relationship with God, which is expressed externally through public or private worship; the cult, for its part, is the set of external demonstrations presented to God; therefore, without the relationship with God, this is without religion, there is no worship.

Thus, the Constitutional Court, in judgment C-616 of November 27, 1997, with the Judge-Rapporteur Vladimiro Naranjo Mesa, established: "Despite the talk of religious pluralism, nevertheless, practices such as the study and experimentation of psychic or parapsychological phenomena, satanism, magical or superstitious or spiritualistic practices and in any case foreign to religion, described in article fifth of the Statutory Law, when it was reviewed by the Court, were excluded, placing a clear limitation to religious pluralism"(Naranjo M., 1997).

The definition of freedom of worship is found in Article 19 of the Political Constitution, by virtue of which everyone has the right to freely profess their religion and spread it individually or collectively "and in judgment T-430 of 1993: "As a complement to freedom of religion, freedom of religion is guaranteed; that is, the right of everyone to celebrate ceremonies, rites or acts, in accordance with their own religious convictions, as well as not to practice any cult without being punished or pressured to compel them to do so " (Corte Constitucional, 1991).

In relation to freedom of conscience, it is important to start from the provisions of the 1991 Constitution in Article 13, which states: "All people are born free and equal before the law, will receive the same protection and treatment from the authorities and will enjoy the same rights, freedoms and opportunities without any discrimination based on sex, race, national or family origin, language, religion, political or philosophical opinion. The State will promote the conditions so that equality is real and effective and will adopt measures in favor of discriminated or marginalized groups" (Corte Constitucional, 1991). 
Additionally, the Political Constitution of Colombia establishes that the quality of equality that all people have before the law is based on the recognition of individuality and the ability to determine life within the framework of State protection. Consequently, the right to religious freedom as it is a fundamental right is directly protected from all forms of discrimination; Now, in Article 18, it establishes: "Freedom of conscience is guaranteed. No one shall be harassed on account of his convictions or beliefs, compelled to reveal them, or compelled to act against his conscience" (Corte Constitucional, 1991).

The right to freedom of conscience and worship, "will be interpreted in accordance with international human rights treaties ratified by the Republic."(Congreso de la Republica de Colombia, 1994) ; the law describes and develops the rights mentioned in the social fields, such as the establishment of places of worship, the private and public profession of the religion practiced, the fulfillment of activities related to education, regulation against legal entities and autonomy of churches and religious confessions, among others.

Lastly, it is important to note that under the constitutional block and pursuant to Article 93 Superior, international instruments such as the Universal Declaration of Human Rights, the American Convention on Human Rights or the Pact of San José de Costa Rica ${ }^{8}$, among others, have enshrined the guarantee and importance of the rights of conscience and religion, and their preeminence for being directly linked to the person and his dignity. "Consciousness constitutes the central and basic nucleus of the personality of the human being, it structures the ethical conformation of the human person, enabling the moral integrity of the individual and the free development of his personality. Freedom of conscience protects the rational, reflective process, the intellectual elaboration of the human being and its adherence or not to value conceptions or beliefs, be they religious, philosophical, ideological, political or of any other nature, as well as to reject those that it considers wrong; process that corresponds to the internal forum of the person who has an inviolable character, which raises a requirement to behave externally in accordance with such conceptions. In short, it is the power of every person to form their own judgment, without any type of interference; the right to think freely, which makes it possible to select or determine values according to which he formulates his life project and the conformation to said thought of his external personal and social activity" (Nogueira A., 2016).

\subsection{Religious tolerance}

The study carried out in which tolerance is exposed, as a sample of civilization and progress, advanced in the thesis arguments for religious tolerance in Colombia, 1832 - 1853, presents arguments that in light of the 1991 Constitution and despite having passed a period of twenty-five years, in force when it is stated: "In the midnineteenth century a liberal newspaper affirmed that religious fanaticism was opposed to religious tolerance, the principle of fanaticism being 'die who does not think as I do.' To make reason succeed, tolerance was necessary. Tolerating was not "admitting mistakes", it was "not persecuting those who [professed] them". It was indicated that whoever tried to impose "a religion or a Government" on the people by force, "slaughtering" whoever opposed him, went against the beliefs of that people. Tolerance was the "conservative virtue" of "democratic" societies, from which it was inferred that "the savages [were] all intolerant" in their religious beliefs. In this way, its defenders showed religious tolerance as a virtue of civilization"(Cortés Guerrero, 2017).

Outside the religious environment, what is established in the Universal Declaration of Human Rights must prevail ; Article 18: "Everyone has the right to freedom of thought, conscience and religion; This right includes the freedom to change religion or belief, as well as the freedom to express your religion or belief, individually and collectively, both publicly and privately, through teaching, practice, worship and observance. "(Organizacion de las Naciones Unidas, 1948). 


\subsection{Religious Intolerance}

"It is a form of intolerance against the religious beliefs or practices (or lack thereof) of a person or group. It may be motivated by different religious beliefs as well as by other kinds of ideologies, as well as anti-religious sentiment . "(Wikipedia, 2020b) f. Religious persecution. Considering that religious persecution is increasing worldwide, at the United Nations General Assembly held in New York on May 27, 2019, by resolution it was declared on August 22 of each year, as the "International day of commemoration of victims of acts of violence based on religion or belief "; According to which: "No one should be persecuted for their faith," all States are also urged to ensure that their laws and policies are in line with their commitments to protect religious freedom under international law. "This international day will help raise awareness of the plight of Christians and other religious minorities who are persecuted and who are denied fundamental rights. All people have the right to freely choose and live their faith. We urge all governments to uphold this fundamental right and protect minorities. said Paul Coleman, executive director of ADF International. Persecution based on religion or belief cannot be allowed and victims should never be forgotten. All people have the right to live their faith peacefully" (Coleman, 2019).

The Universal Declaration of Human Rights was adopted by the third United Nations General Assembly, proclaimed by the United Nations General Assembly in Paris, on December 10, 1948 in its Resolution 217 A (III). The Pontifical Foundation ACN Colombia Helps the Suffering Church, invited the Polish missionary Dominik Kustra, who said "that in the 21st century there are at least 400 million Christians suffering persecution for the faith, which can be seen from various angles, as for matters of faith, but another more relevant: as a denial of one of the most important human rights: freedom of conscience and religion" (ACN Colombia, 2015). He also said that there are different modes of discrimination, such as persecution and displacement, war, etc. But in the West it is treated with ridicule, indifference and silence of spiritual facts, it is fought for the claim of sexual rights, for the ethnic or racial claim, but not for the rights to religious freedom.

Among the painful topics discussed was the difficult situation of the Church in Venezuela, where without resources, but with firm faith, pastors feed the people and provide medications, which they would otherwise be unable to obtain.

\subsection{Discrimination for Religion}

It consists of treating a person or group in an unfavorable way due to their religious beliefs. This includes when the followers of different religions, denominations or religions are treated unequally because of these beliefs, either at law or in institutional settings, such as employment or housing."(Wikipedia, 2020a). It is related to the persecution religious, the more extreme form that includes instances in which people have been executed for beliefs perceived as heretics.

The United Nations has dealt with this issue and in support of the Special Rapporteur on freedom of religion or belief, the Commission on Human Rights and the Committee on Economic, Social and Cultural Rights, has prohibited religious discrimination established in the main international deals. States have a duty to refrain from discriminating against individuals or groups based on their religion or belief, they have a duty to prevent this discrimination and must take the necessary measures to guarantee that in practice the people who are in their territory, enjoy all human rights without discrimination.

\subsection{Who are subjects of religious freedom}

Regarding the subjects of rights, reference will be made to the observations made in this regard, in which he refers: Precisely because freedom is studied as a right, it is essential to mention the subjects entitled to this right. Now, it is the duty of the State to recognize the fundamental right of religious freedom, promote the respect and 
protection of this right, adopt effective measures to protect the religious freedom of every person residing in its territory. If he tried to prevent, direct or impose the ordination of the person to God - or to believe in Him - he would be committing an excess. In this case, the State would go beyond its competence, fully exceeding its functions and ignoring the protection of human rights that are recognized both internationally and locally. But this right could also be affected if the State does not know, in this case by default, the social dimension that the ordination of the person to God has, for example, preventing the work of religious confessions and churches for the full fulfillment of their own duties of religiosity; or if he assumes the right to judge the truth or adopt an attitude of hostility against the religious act. Society must also protect religious freedom, prevent the right that corresponds to each person in relation to their religious beliefs, or their refusal to demonstrate a position before the faith, be ignored or violated. In the same way, they also have duties, although of another nature, the churches and religious confessions. We must not forget that the right of the person is with respect to the civil order, not the religious order, in this way their duties are related to the religious creed they profess.

\subsection{General principles of religious freedom}

In the decree that develops the Fundamental Public Policy of religious freedom and cults for the District of Bogotá, the general principles have been established based on human rights, participatory of women in conflict resolution in the consolidation of peace and reconciliation, as well as an intercultural approach, a spiritual approach and religious beliefs as well as a territorial one, however, due to the contribution that this study represents, the Family Approach will be pointed out. Accordance with article 16 of the Universal Declaration of Human Rights and in harmony with article 42 of the Political Constitution of Colombia, the family is recognized as the fundamental nucleus of society. This means that the balance of the family is intimately linked to the very balance of society, since from the family human life is structured, the first psycho-affective relationships are established, the first regulations of conduct, basic ethical standards, moral values, the formation of personality, the first context of education and of social and civic experiences. The family is considered the primary social network that provides spiritual, emotional and material support, primarily in extreme and adverse circumstances. The protection factor that families offer is positively related to spiritual, psychic, physical and psychosocial aspects. In this sense, the churches are key in the protection, prevention and in dealing with conflicts that arise within them.

The family approach has been chosen in the present investigation, since from the experience in Family Police Stations in the different localities of Bogotá, it was revealed that there is violence for religious freedom in families, but that, having to be identified when less as a factor that generates intra-family violence, it does not happen and even less as a form of violence by families, who refrain from reporting as evidenced in the survey conducted during the first half of the year two thousand and nineteen (2019) to three hundred and fifty (350) people in the twenty (20) localities of the city of Bogotá and by the Institution who in turn refrain from proffering protection measures to the victims, as it is a fundamental right without identity, therefore, presumably they have not been trained in the topics developed here and consequently they abstain from availing themselves of current international regulations and national according to the constitutional block.

\subsection{Characteristics of the right to religious freedom}

In line with the studies carried out by (Madrid-Malo, 1996), the right to religious freedom of worship and conscience has the following characteristics: "It is a fundamental right; It is an inalienable right, it is a tutelable right; It is a right of immediate application; It is a non- suspended right; It is an intangible right; It is a right that can only be regulated by statutory law". 


\subsection{Rights related to religious practice}

The right to religious and religious freedom implies, as such, the freedoms of expression and external expression of the religious convictions or beliefs adopted, that is, generically, the right to religious freedom; therefore, in this field, many and very diverse manifestations are possible, which find full protection in international human rights law as well as in national regulations; consequently, in accordance with the studied norms, the following rights are protected and guaranteed: To spread religious convictions or beliefs, individually or collectively, publicly or privately; Freely express religious convictions or beliefs, or the absence thereof; Practice acts of prayer and worship, individually or collectively, in private or in public; Not being forced to practice acts of worship contrary to your convictions is personal; Gather or demonstrate publicly for religious purposes; Receive a decent burial in accordance with the precepts and rites of the religion of the deceased in all matters relating to funeral customs; Receive religious assistance from your own religious denomination or church, wherever you are and mainly in public places of medical care, in military barracks and in places of detention; Not be forced to receive religious assistance contrary to personal religious convictions or beliefs ; Build, establish, and maintain places of worship; Celebrate religious rites and practices; Observe holidays and religious rest days; Display symbols consistent with religious beliefs or convictions; Wearing clothing in accordance with religious convictions or beliefs; Carry special diets; Use specific language; Found and maintain charitable or humanitarian institutions; Make, acquire and use, in the quantity that is required, articles and materials necessary for the rites or customs of a religion or conviction; Request and receive voluntary financial and other contributions from individuals and institutions; Establish and maintain communications with individuals and communities about matters of religion or convictions at the national and international levels; Protection of places of worship, even in the event of war; Protection of religious persons or objects, against grievances or damages that may be inflicted on them; Worship the dead.

\subsection{Limits on the exercise of the right to religious freedom}

In the last ten years, the Constitutional Court has issued judgments of guardianship in which reference is made to the issue of limits in the exercise of the right to religious freedom, worship and conscience, it is a matter of special relevance taking into account that it is not an "unrestricted and erga omnes" right and that it finds limits based on respect for the rights of others, it is necessary to refer initially to the International Conventions to which we will refer. In the same sense, the State Council in judgment 01392/2014, states in this regard "By virtue of this, the content and scope of religious freedom, like all fundamental rights, is also subject to certain limits, which are none other than the rights of others, which allows the legitimate exercise of their own rights, those of others and demands such as public order, public health and safety, morality and tranquility that make possible peaceful coexistence in society" (Consejo de Estado, 2014).

\section{Conclusions}

Finally, the person is also subject of this duty. No one may, by reason of his beliefs, or for any other reason, prevent another person or group of persons from freely professing their religion or from refusing or professing any. Neither does it force her to reveal it or act against her religious beliefs.

It is necessary to promote a culture of respect and tolerance for the fundamental freedoms of religion, worship and conscience through the adoption, socialization and implementation of the Fundamental Public Policy on Religious Freedom in Bogotá, which constitutes the full exercise of the guarantees that the Constitution establishes for the benefit and recognition of the importance of families in society.

The difference of religions is considered as a triggering factor of violence in the preliminary identification instrument of risk to life and personal integrity due to violence within the family. 


\section{Bibliographic references}

ACN Colombia. (2015). En pleno siglo XXI hay persecución religiosa. Cristianos, los más afectados - ACN Colombia. Retrieved October 30, 2020, from Fundación Pontificia website: https://www.acncolombia.org/en-pleno-siglo-xxi-hay-persecucion-religiosa-cristianos-los-mas-afectados/

Coleman, P. (2019). UN creates new international day condemning religious persecution. Retrieved October 30, 2020, from ADF International website: https://adfinternational.org/news/un-creates-new-internationalday-condemning-religious-persecution/

Congreso de la Republica de Colombia. (1994). Ley 133 de 1994. Retrieved October 30, 2020, from Diario Oficial website: http://www.secretariasenado.gov.co/senado/basedoc/ley_0133_1994.html

Consejo de Estado. (2014). Sentencia 01392/2014.

Corte Constitucional. (1991). Constitución Política de Colombia. Diario Oficial. Retrieved from http://www.corteconstitucional.gov.co/inicio/Constitucion politica de Colombia - 2015.pdf

Cortés Guerrero, J. D. (2017). Argumentos por la tolerancia religiosa en Colombia, 1832-1853. Historia y Sociedad, (33), 45-76. https://doi.org/10.15446/hys.n33.61099

Madrid-Malo, M. (1996). Sobre las libertades de conciencia y de religión. Bogotá (Colombia): Defensoria del Pueblo.

Naranjo M., V. (1997). C-616-97 Corte Constitucional de Colombia. Retrieved October 30, 2020, from https://www.corteconstitucional.gov.co/relatoria/1997/C-616-97.htm

Nogueira A., H. (2016). La libertad de conciencia, la manifestación de creencias y la libertad de culto en el ordenamiento jurídico chileno. Revista lus Et Praxis, 12(2), 13-41.

Organizacion de las Naciones Unidas. (1948). La Declaración Universal de Derechos Humanos | Naciones Unidas. Naciones Unidas, p. Página web. Retrieved from https://www.un.org/es/universal-declarationhuman-rights/

United Nations. (1966). OHCHR | International Covenant on Civil and Political Rights. Retrieved October 30, 2020, from https://www.ohchr.org/en/professionalinterest/pages/ccpr.aspx

Wikipedia. (2020a). Discriminación religiosa. Retrieved October 30, 2020, from Wikipedia website: https://es.wikipedia.org/wiki/Discriminación_religiosa

Wikipedia. (2020b). Intolerancia religiosa. Retrieved October 30, 2020, from Wikipedia website: https://es.wikipedia.org/wiki/Intolerancia_religiosa

Esta obra está bajo una Licencia Creative Commons Attribución-NoCommercial 4.0 International

(c) B BY-NC 